\title{
Kontribusi Teknologi Informatika dalam Pembangunan Industri dan Sumber Daya Manusia
}

\author{
Oleh : Moses L. Singgih
}

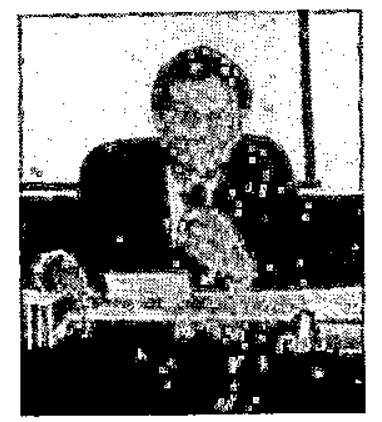

Moses Laksono Singgih; lahir di Madiun tanggal, 17 Agustus 1959. Menyelesaikan Sarjana Teknik Industri dan Masterdalambidang TeknikdanManajemen Industri diITB Bandung. Selain ituiajuga menyelesaikan Master of Regional Science \& Doktor dalam Bidang Economics dari University of Queensland, Australia. Disamping sébagai Dosen jurusan Teknik Industri, ITS ia juga menjabat sebagai Sekretaris Jurusan Teknik Industri, Ketua Laboratorium Simulasi Industri dan Ketua Labora torium Sistem Penunjang Keputusan ITS Surabaya.

\section{Pendahuluan}

Informasi merupakan salah satu sumber daya yang sangat penting di dalam suatu organisasi. Sumber dari informasi adalah data. Data adalah kenyataan yảng menggambarkan suatu kejadian-kejadian. Kejadian-kejadian adalah suatu yang terjadi pada saat yang tertentu. Data yang tersedia mungkin dapat langsung dimanfạatkan untuk pengambilan keputusan tetapi mungkin saja tidak bermanfaat. Dibandingkan dengan data, informasi pasti bermanfaat bagi pengambil keputusan. Jadi informasi adalah data yang bermanfaatatau data yang telah diproses sehingga bermanfaat bagi pengambilan keputusan.

Kualitas dari suatu informasi tergantung dari tigà hal, yaitu informasi harus akurat, tepat pada waktunya dan relevan (Yogianto, 1993). Akurat berarti informasi harus bebas dari kesalahankesalahn dan harus diterima oleh orang yang seharusnyamenerima informasi.Tepat pada waktunya berarti informasi yang datang pada penerima tidak boleh terlambat. Informasi yang sudah usang tidak akan mempunyai nilai lagi. Relevan berarti informasi tersebut mempunyai manfaat untuk pemakaiannya. Relevansi informasi untuk tap-tiap orang satu dengan yang lainnya berbeda.

Teknologi informatika berkembang sangat pesatkarenapesatnyaperkembangan komputer.Pada mulanya ukuran komputer sangat besar tetapi kecepatannya rendah.Namunukuran komputer bertambah - kecil dan kecepatannya meningkat pesat. Komputer sebagai pengolah data jauh lebih cepat dan lebih akurat dibandingkan dengan manusia. Keunggulan komputer sebagai 
pengolah data inilah yang "melahirkan" bidang teknik baru yaitu Teknologi " Informatika.

\section{Pengembangan Industri.}

Industri adalah kumpulan dari perusahaan-perusahaan yang memproduksi barang atau jasa sejenis. Pengembangan suatu industri tidak dapat dipidahkan dari perkembangan tiap-tiap perusahaan secara terpisah. Jadi untuk mengembangkan suatu industri, seluruh perusahaan harus dikembangkan secara bersama-sama.

Peningkatan kompetisi dalam industri telah merangsang perusahaanperusahaan untuk meningkatkan produktivitas. Peningkatan produktivitasini memungkinkan suatu perusahaan memproduksi dengan biaya yang lebih murah dengan kualitas yang lebih tinggi. Salah satu cara untuk meningkatkan produktivitas adalah pemakaian komputer untuk mengelola perencanaan dan pengendalian produksi di pabrik.

Perencanaan dan pengendalian produksi bertujuan untuk :
1. Memaksimumkan pelayanan kepada konsumen yaitu waktu pelayanan yang cepat dan konsumen mendapatkan barang yang sesuai.

2. Meminimumkan 'investasi untuk persediaan barang. Yang termasuk dalam persediaan ialah pérsediaan bahan baku, barang dalam proses, dan produk jadi. Kelebihan persediaan merugikan karena modal yang tertanam dalam persediaan, semestinya dapat digunakan untuk keperluan yang lain.

3. Memaksimumkan efiensi pemakaian mesin. Penjadwalan pemakaian mesin perlu dilakukan sehingga dapat memanfaatkan pemakaianmesin-mesin secara efisien.

Diagram tentang perencanaan dan pengendalian produksi dapat dilihat pada Gambar 1. Tíap kotak pada Ganibar 1 merupakan subsistem yang mempunyai fungsi tersendiri. Arah panah menunjukkkan aliran informasi dari satu subsistem dan subsistem lainnya. Tiap subsistem ini ditunjang oleh program komputer dan dihubungkan dengan subsistem-subsistem yang lain. 


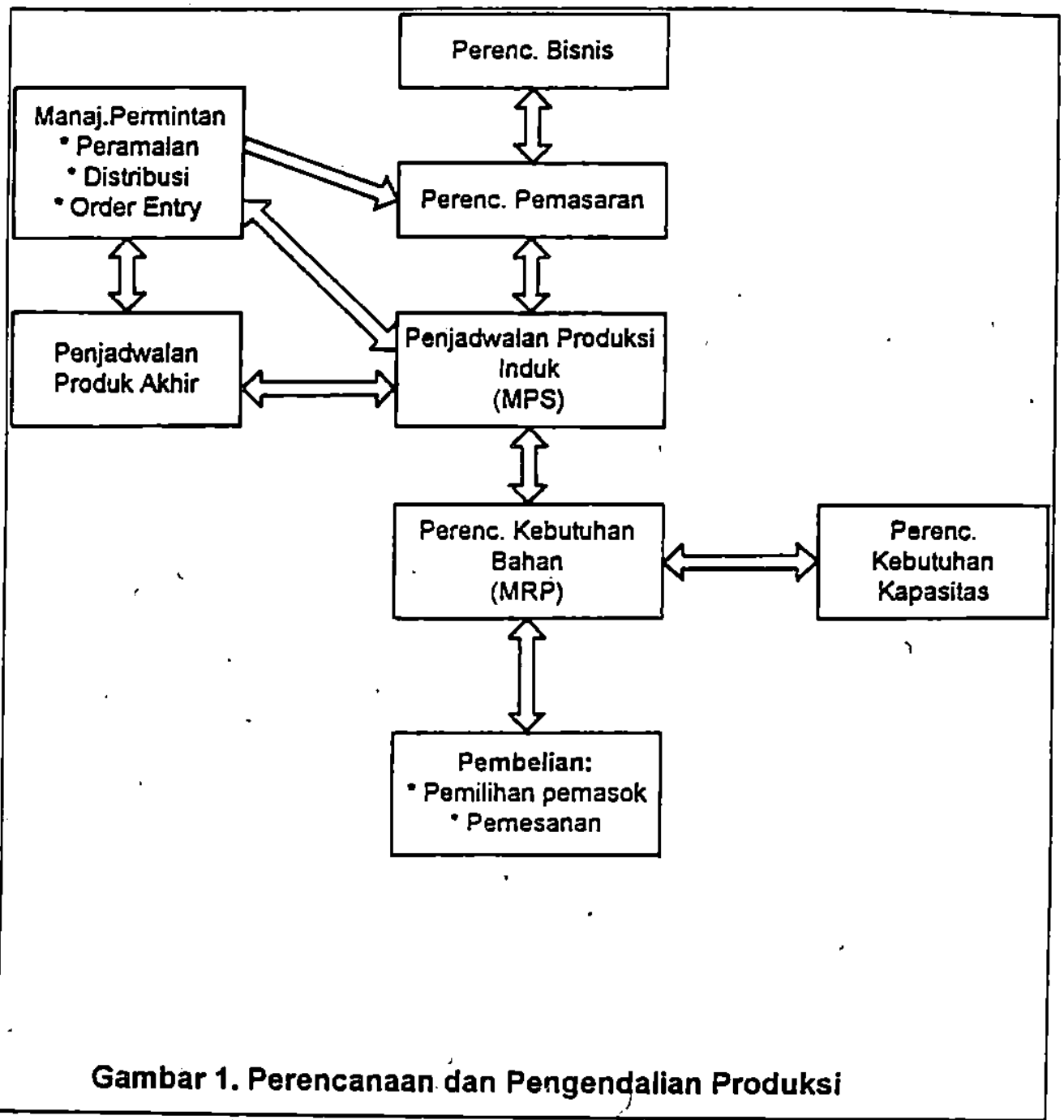

Perencanaan bisnis merupakan rencana perusahaan dalam bentuk rupiah. Dalam perencanaan ini temasuk Laporan Rugi Laba, Nereaca, sumber dan pemanfaatkan anggaran juga ukuran-ukuran kińerja seperti pengembalian modal, earning per share, dan lain-lain.

Perencanaan pemasaran meliputi produk yang dibuat. daerah pemasaran, saluran distribusi dan market share.
Penjadwalan produksi induk (MPS) menunjukkan banyaknya produk harus dibuat dalam horisma perencanaan.

Manajemen permintaan merupakan semua aktivitas tentang permintaan yaitu peramalan permintaan; pendistribusian produk yang telah jadi dan memasukkan pesanan (order entry).

Penjadwalan produk akhir merupakan subsistem, yang berfungsi untuk 
menentukan kapan proses produksi harus diselesaikan.

Perencanaan kebutuhan bahan (MRP) mérupakan perencanaan pembuatan/ pembelian komponen atau bahan baku yang harus disesuaikan dengan MPS, kapasitas produksi dantenggang waktu pembelian.

Perencanaan kebutuhan kapasitasadalah modul yangmemakai data-data MRP untuk menentukan apakahkapasitas produksi saat ini sudah mencukupi atau belum. Jika kapasitasproduksi sat ini belum mencukupi, penambahan kapasitas dalam jangka pendek dapat dilakukan dengan lembur, atau penambahan shift kerja. Sedangkan dalam jangka panjang mungkin perlu penambahan fasilitas produksi.

Fungsi pembelian meliputi pemilihan pemasok, rencana pemesanan.

\section{Sumber Daya Manusia}

Sumber daya manusia merupakan faktor produksi yang sangat penting diperhatikan dalam perusahaan. Baik perusahaan manufaktur atau jasa, perusahaan berteknologi tinggi maupun rendah, pasti memerlukan manusia sebagai input produksi.

Seperti yang terlihat pada Gambar 2 , suatu proses produksi (pạbrik, rumah sakit, bank dil) memerlukan input produksi berupa material, manüsia, mesin dan peralatan, energi dan informasi. Input-input ini diolah dalam suatu proses produksi sehingga menghasilkan produk akhir berupa barang jasa, informasi dan juga limbah.

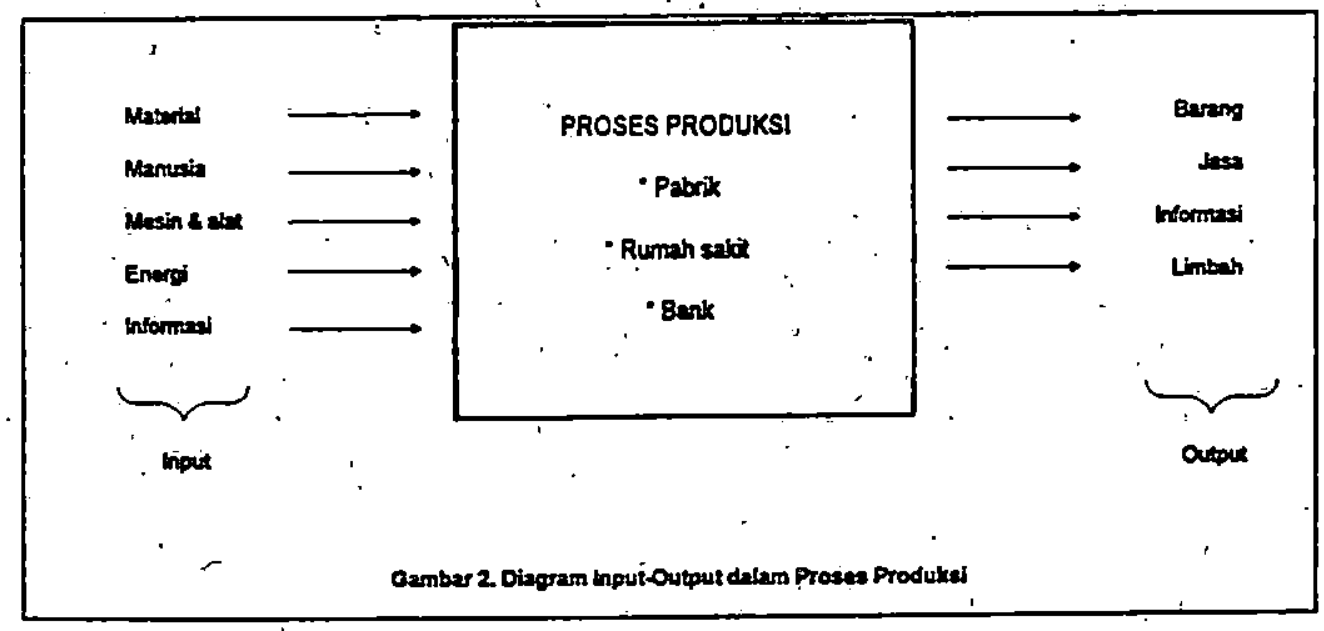


Manusia sebagai input produksi tidak dapat dipandang hanya sebagai input yang pasif seperti input lainnya, melaikan manusia juga merupakan faktor produksi aktif. Sebagai input produksi, manusia tersebut tidak hanỹa dilihat dari kekuatan fisiknya (input pasif) .melainkan juga pikiran, motivasi dan perilakunya (input aktif).

Peranan manusia sebagai input produksi lebih dominan dibandingkan dengan input-input produksi lainnya karena manusia dapat mengolah beberapa informasi yang diterimanya, menyesuaikan dengan kondisi pada saat itu dan kemudian mengambil keputusan yang tepat.

Karena informasi merupakan landasan di dalam pengambilan keputusan. Bila pengambilan keputusan terlambat, makadapat berakibat fatal untuk organisasi. Dewasa ini mahalnya nilai informasi disebabkan harus cepatnya informasi tersebut didapat, sehingga diperlukan teknologi-teknologi mutakhir untuk mendapatkan, mengolah dan mengirimkannya. Disinilah peranan teknologi informatika.

Teknologi informatikalebih penting lagi dalam hal mengolah informasi karena informasi yang diperlukan harsulah reevan dengan tingkatan manajemen dan bidang yang ditangani oleh pengambil keputusan.

Makin tinggi kedudukan seseorang dalam suatu organisasi, dia memerlukan infomasi yang makin global dan lebih bersifat ekstemal. Sebaliknya, operator mesin memerlukán informasi yang terperinci dan bersifat intermal.

\section{Kesimpulan dan Saran.}

Teknologi informatika adalah sarana yang ampuh untuk pembangunan industri dan membantu manusia dalam mengambil keputusan.

Keakuratan informasi, banyaknya informasi yang harus diolah dan sifat informasi yang berbeda bagi berbagai level manajementidaklah mungkin dilaksanakan tanpa dukungan teknologi informatika yang canggih:

Untuk meningkatkan daya saing industri Indonesia, perusahaan-perusahaan seharusnya memanfaatkan komputersecara terintegrasi untuk mengolah data dan menyajikan di semua departemen sehingga diperoleh informasi yang cepat dan akurat.

Meskipun teknologi infonmatika ini dapat meningkatkan daya saing industri tetapi meperapannya masih meemerlukan waktu yang cukup panjang. Pemakai komputer haruslah tidak takut memakai komputer karena program komputer telah dirancang untuk mempermudah pengambilan keputusan. Penjelasan ini perlu diberikan kepada pengambil keputusan yang akan memakai komputer.

Sebaliknya, pembuatan program komputer yang efisien merupakan tugas dari ahli teknologi informatika. Pendidikan ahli teknologi informatika diperlukan sekali untuk membantu pengambil keputusan dalam hal membuat program komputeryang user friendly.

\section{Daftar Pustaka}

Jogiyanto, H.M., 1993, Analisis dan Disain Sistem. Informasi : Pendekatan Terstruktur, Andi Offset, Yogyakarta.

Kroeber, D.W., and Watson, HJ., 1990, Computer-Based Information system : A Management Approach, Macmillan Publishing Company, New York. 
McLeod, R, JR., 1993, Management Informa$\checkmark$ tion Sysiem, Macmillan Publishing Company, New York.

Sanders, D.H.. 1988, Computer Today, McGraw-Hill International Editions.
Singapore.

Smith,S.B., 1989, Computer BasedProduction and Inventory Control, Prentice-Hall International Editions. Englewood Clifls. 